NASA/CR-2000-210510

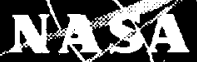

Modeling Film-Coolant Flow Characteristics at the Exit of Shower-Head Holes

Vijay K. Garg

AYT Corporation, Brook Park, Ohio 
Since its founding, NASA has been dedicated to the advancement of aeronautics and space science. The NASA Scientific and Technical Information (STI) Program Office plays a key part in helping NASA maintain this important role.

The NASA STI Program Office is operated by Langley Research Center, the Lead Center for NASA's scientific and technical information. The NASA STI Program Office provides access to the NASA STI Database, the largest collection of aeronautical and space science STI in the world. The Program Office is also NASA's institutional mechanism for disseminating the results of its research and development activities. These results are published by NASA in the NASA STI Report Series, which includes the following report types:

- TECHNICAL PUBLICATION. Reports of completed research or a major significant phase of research that present the results of NASA programs and include extensive data or theoretical analysis. Includes compilations of significant scientific and technical data and information deemed to be of continuing reference value. NASA's counterpart of peerreviewed formal professional papers but has less stringent limitations on manuscript length and extent of graphic presentations.

- TECHNICAL MEMORANDUM. Scientific and technical findings that are preliminary or of specialized interest, e.g., quick release reports, working papers, and bibliographies that contain minimal annotation. Does not contain extensive analysis.

- CONTRACTOR REPORT. Scientific and technical findings by NASA-sponsored contractors and grantees.
- CONFERENCE PUBLICATION. Collected papers from scientific and technical conferences, symposia, seminars, or other meetings sponsored or cosponsored by NASA.

- SPECIAL PUBLICATION. Scientific, technical, or historical information from NASA programs, projects, and missions, often concerned with subjects having substantial public interest.

- TECHNICAL TRANSLATION. Englishlanguage translations of foreign scientific and technical material pertinent to NASA's mission.

Specialized services that complement the STI Program Office's diverse offerings include creating custom thesauri, building customized data bases, organizing and publishing research results ... even providing videos.

For more information about the NASA STI Program Office, see the following:

- Access the NASA STI Program Home Page at http://www.sti.nasa.gov

- E-mail your question via the Internet to help@sti.nasa.gov

- Fax your question to the NASA Access Help Desk at (301) 621-0134

- Telephone the NASA Access Help Desk at (301) 621-0390

- Write to:

NASA Access Help Desk

NASA Center for AeroSpace Information 7121 Standard Drive

Hanover, MD 21076 
NASA/CR-2000-210510

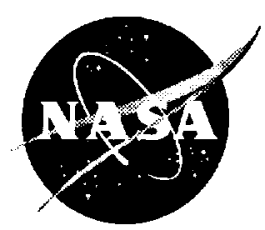

\section{Modeling Film-Coolant Flow Characteristics at the Exit of Shower-Head Holes}

Vijay K. Garg

AYT Corporation, Brook Park, Ohio

Prepared for the

2000 International Mechanical Engineering Congress and Exposition sponsored by the American Society of Mechanical Engineers

Orlando, Florida, November 5-10, 2000

Prepared under Contract NAS3-98106

National Aeronautics and

Space Administration

Glenn Research Center 


\section{Acknowledgments}

The author wishes to thank Dr. Raymond Gaugler, Chief, Turbine Branch at the NASA Glenn Research Center, for his support of this work.

Available from

NASA Center for Aerospace Information 7121 Standard Drive

Hanover, MD 21076

Price Code: A03
National Technical Information Service 5285 Port Royal Road Springfield, VA 22100

Price Code: A03

Available electronically at http://gltrs.grc.nasa.gov/GLTRS 


\title{
MODELING FILM-COOLANT FLOW CHARACTERISTICS AT THE EXIT OF SHOWER-HEAD HOLES
}

\author{
Vijay K. Garg \\ AYT Corporation \\ NASA Glenn Research Center \\ Mail Stop 5-11, Cleveland, $\mathrm{OH} 44135$ \\ Tel: 216-433-6788; Fax: 216-433-5802 \\ e-mail: vijay.garg@grc.nasa.gov
}

\begin{abstract}
The coolant flow characteristics at the hole exits of a film-cooled blade are derived from an earlier analysis where the hole pipes and coolant plenum were also discretized. The blade chosen is the VKI rotor with three staggered rows of shower-head holes. The present analysis applies these flow characteristics at the shower-head hole exits. A multi-block three-dimensional Navier-Stokes code with Wilcox's $k$ - $\omega$ model is used to compute the heat transfer coefficient on the film-cooled turbine blade. A reasonably good comparison with the experimental data as well as with the more complete earlier analysis where the hole pipes and coolant plenum were also gridded is obtained. If the $1 / 7$ th power law is assumed for the coolant flow characteristics at the hole exits, considerable differences in the heat transfer coefficient on the blade surface, specially in the leading-edge region, are observed even though the span-averaged values of $h$ match well with the experimental data. This calls for span-resolved experimental data near film-cooling holes on a blade for better validation of the code.
\end{abstract}

\section{NOMENCLATURE}

c true chord of the blade

$c_{x} \quad$ axial chord of the blade

d coolant hole diameter

h heat transfer coefficient based on $\left(T_{0}-T_{w}\right)$

$\mathrm{k}$ turbulence kinetic energy

$\ell$ turbulence length scale

m mass flow rate

M Mach number; also leading-edge mid-row hole at $s / c=0$

p pressure

$\mathrm{P} \quad$ leading-edge hole on the pressure side at $\mathrm{s} / \mathrm{c}=-0.031$

Pr Prandtl number

$R$ the gas constant

Re Reynolds number

s distance from the leading edge along the pressure or suction surface; also local hole-coordinate

$\mathrm{S} \quad$ leading-edge hole on the suction side at $\mathrm{s} / \mathrm{c}=0.031$
T temperature

Tu turbulence intensity

$\mathrm{v}^{*} \quad$ shear velocity

$\mathrm{V}$ magnitude of velocity

$\mathrm{x}, \mathrm{y}$ Cartesian coordinate system with origin at the geometric stagnation point

$z \quad$ local hole-coordinate

$\mathrm{y}^{+} \quad$ distance in wall coordinates $\left(=\mathrm{yv}^{*} / \mathrm{v}\right)$

$\alpha$ thermal diffusivity

$\Delta y$ distance (from the wall) of the first point off the wall

$\varepsilon \quad$ turbulence dissipation rate

$\mu \quad$ viscosity

$v \quad$ kinematic viscosity

$\rho$ density

$\omega \quad$ specific turbulence dissipation rate $(=\varepsilon / \mathrm{k})$

\section{Subscripts}

$\begin{array}{ll}\text { av } & \text { average value } \\ \text { c } & \text { for coolant; also corresponding to true chord of the blade } \\ \text { ef } & \text { effective value } \\ \text { ex } & \text { value at exit } \\ \text { in } & \text { value at inlet } \\ \ell & \text { laminar value } \\ \text { o } & \text { stagnation value } \\ \text { s } & \text { isentropic value } \\ \text { T } & \text { turbulent value } \\ \text { W } & \text { value at wall }\end{array}$

\section{INTRODUCTION}

It is well known from the thermodynamic analysis that the performance of a gas turbine engine is strongly influenced by the temperature at the inlet to the turbine. There is thus a growing tendency to use higher turbine inlet temperatures, implying increasing heat loads to the engine components. Modern gas turbine engines are designed to operate at inlet temperatures of $1800-2000 \mathrm{~K}$, which are far beyond the allowable metal temperatures. Thus, to maintain acceptable 
life and safety standards, the structural elements need to be protected against the severe thermal environment. This calls for an efficient cooling system. One such cooling technique currently used for high temperature turbines is film cooling. In this technique, cooler air is injected into the high temperature boundary layer on the blade surface. Since the injected cooler air is bled directly from the compressor before it passes through the combustion chamber, it represents a loss in the total power output. The designer's goal is therefore to minimize the amount of coolant necessary to insure adequate engine life. Unfortunately, the thermal design of a film-cooled blade is still based on one-dimensional analysis and empirical correlations, thereby requiring actual testing of every design concept. In such a situation, only minor variations of existing designs are adopted since any novel ideas are too expensive to test thoroughly. There is thus an urgent need to be able to predict accurately the heat transfer characteristics of film-cooled blades before actually testing them in the engine.

A considerable effort has been devoted to understanding the coolant film behavior and its interaction with the mainstream flow. The film cooling performance is influenced by the wall curvature, three-dimensional external flow structure, free-stream turbulence, compressibility, flow unsteadiness, the hole size, shape and location, and the angle of injection. Interest in this field has grown considerably in recent years. However, many studies on film cooling have been confined to simple geometries, for example, two-dimensional flat and curved plates in steady, incompressible flow.

An excellent survey of the film-cooling work up to 1971 has been provided by Goldstein (1971). Several further studies in this field have been summarized by Garg and Gaugler $(1993,1994,1996)$. A number of parametric studies have been performed by Garg and co-workers to determine the effect of several parameters, such as the effect of coolant velocity and temperature distributions at the hole exit (Garg and Gaugler, 1997), and the effect of turbulence modeling (Garg and Ameri, 1997; Garg, 1999). Four turbulence models, the BaldwinLomax model, Coakley's q- $\omega$ model, Chien's k- $\varepsilon$ model, and Wilcox's $k-\omega$ models have been analyzed, and results compared with the experimental data for heat transfer from rotating as well as stationary blades. In all these studies by Garg and co-workers, coolant velocity and temperature distributions were prescribed at the hole exits; there was no attempt to analyze the coolant within the plenum and holepipes. A recent study by Garg and Rigby (1999) analyzed in detail the coolant flow structure issuing out of three staggered rows of compound-angled holes on a real blade, and its interaction with the mainstream. This study also surveyed the existing literature on the hole-exit distributions based on computational as well as experimental studies.

It is well known that a film-cooled blade has hundreds of holes out of which the coolant is ejected. In order to predict the heat transfer characteristics accurately on such a blade, it is intuitive to follow the coolant from the plenum into the hole pipe and out of every hole exit. However, for hundreds of holes on the blade, generation of a reasonable grid while tracing the coolant from the plenum to every hole exit and beyond becomes insurmountable. The problem is much more tractable if the coolant flow characteristics could be specified at the hole exits on the blade, without going inside every hole. Even in such a case, grid generation is not trivial, and leads to at least a couple of million grid cells (Garg, 2000). For the present work, therefore, the coolant flow characteristics at the hole exits were derived from an earlier analysis where the hole pipes and coolant plenum were also discretized (Garg and Rigby, 1999). The present analysis applies these flow characteristics at the shower-head hole exits. The blade chosen is the VKI rotor with three staggered rows of shower-head holes. A multi-block three-dimensional Navier-Stokes code with Wilcox's $k$ - $\omega$ model is used to compute the heat transfer coefficient on the filmcooled turbine blade.

\section{ANALYSIS}

The numerical simulation has been performed using the NASA Glenn Research Center General Multi-Block Navier-Stokes Convective Heat Transfer code, Glenn-HT. Briefly, the code, formerly known as TRAF3D.MB (Steinthorsson et al., 1997), is an explicit, multigrid, cellcentered, finite volume code with a $k$ - $\omega$ turbulence model without any wall functions. This is a general purpose flow solver designed for simulations of flows in complicated geometries. The Navier-Stokes equations in a rotating Cartesian coordinate system are mapped onto a general body-fitted coordinate system using standard techniques. The multistage Runge-Kutta scheme developed by Jameson et al. (1981) is used to advance the flow solution in time from an initial approximation to the steady state. A spatially varying time step along with a CFL number of 4 is used to speed convergence to the steady state. Eigenvalue-scaled artificial dissipation and variable-coefficient implicit residual smoothing are used along with a full-multigrid method. The overall accuracy of the code is second order. A single-block version of the same code, modified for film-cooling applications, was used by Garg and co-workers for the film cooling studies described earlier. The $k$ - $\omega$ model of Wilcox (1994) with Menter's modifications (Menter, 1993) has yielded good results for heat transfer on film-cooled blades (Garg and Ameri, 1997; Garg, 1999), and is highly desirable for multiblock codes since it does not require the computation of distance from a wall. Also, no wall functions are used, thus avoiding any bias to the complex interactions between the coolant and the mainstream near the blade surface.

It is assumed that the effective viscosity for turbulent flows can be written as

$$
\mu_{e f}=\mu_{t}+\mu_{T}
$$

where the laminar viscosity $\mu_{\mathrm{f}}$ is calculated using a power-law for its dependence on temperature. The turbulent viscosity $\mu_{T}$ is computed using the low-Re $k$ - $\omega$ model described by Garg and Ameri (1997). The turbulent thermal diffusivity is computed from

$$
\alpha_{T}=\frac{\mu_{T}}{\rho P r_{T}}
$$

where a constant value of 0.9 is used for the turbulent Prandtl number, $\operatorname{Pr}_{\mathrm{T}}$.

\section{Boundary Conditions}

At the main flow inlet boundary located at an axial distance equal to $80 \%$ of the blade axial chord upstream of the blade leading edge, the total temperature, total pressure, whirl, and meridional flow angle are specified, and the upstream-running Riemann invariant based on the total absolute velocity is calculated at the first interior point and extrapolated to the inlet. The velocity components are then decoupled 
algebraically, and the density is found from total temperature, total pressure and total velocity using an isentropic relation. For the turbulence model, the value of $k$ and $\omega$ is specified using the experimental conditions, namely

$$
k=1.5\left(u_{i n} T u_{i n}\right)^{2}, \quad \omega=k^{1 / 2} / \ell,
$$

where $T u_{\text {in }}$ is the intensity of turbulence at the inlet (taken to be 0.052 as per experimental data for the VKI rotor), $u_{\text {in }}$ is the inlet velocity, and $l$ is the integral length scale representing the size of the energy containing eddies. This length scale is usually not reported as part of the experimental conditions, and needs to be assumed. For the present study, $l$ was assumed to be $5 \%$ of the blade axial chord which is $62.04 \mathrm{~mm}$. We may add that experimentally turbulence was generated using parallel, horizontal rods of $3 \mathrm{~mm}$ diameter, which is about $5 \%$ of the blade axial chord. Also, it may be noted that for cases where secondary flows due to endwall effects are not present, Garg and Ameri (1997) found negligible difference in the heat transfer coefficient at the surface of a film-cooled blade (the C3X vane; Hylton et al. 1988) under similar mainstream conditions $\left(M_{i n}=0.19, M_{e x, s}=\right.$ $0.9, R e_{c, i n}=6 \times 10^{5}, T u_{i n}=0.065$ and $\ell=0.05$ ) when $T u_{i n}$ was raised to 0.15 , and $\ell$ was taken to be 0.01 or 0.25 at the inlet, using the Chien $k-\varepsilon$ model (Chien, 1982). It is expected that a similar conclusion holds for the $k$ - $\omega$ model as well. Note that endwall effects are of no concem here since the computational span is one spanwise pitch of the holes as explained later.

At the main flow exit plane located at an axial distance equal to $70 \%$ of the blade axial chord downstream of the blade trailing edge, the static pressure is specified and the density and velocity components are extrapolated from the interior. At the solid surface of the blade, the no-slip condition is enforced, and temperature is specified as per experimental data. The boundary conditions for turbulence quantities on the walls are $k=0$, and

$$
\omega=\left.100 \frac{\partial u}{\partial y}\right|_{\text {wall }}
$$

for a hydraulically smooth surface. An upper limit is imposed on the value of $\omega$ at the wall, as suggested by Menter (1993) and found effective by Chima (1996),

$$
\left(\omega_{\max }\right)_{\text {wall }}=\frac{800}{\operatorname{Re}} \frac{v}{(\Delta y)^{2}}
$$

The grid around the blade extends to mid-way between two adjacent blades with periodic flow conditions in terms of cylindrical velocity components set on a dummy grid line outside this boundary. For a linear cascade (which is true for the VKI rotor experiments), it is possible to consider only a part (equal to one spanwise pitch of the holes) of the real span for computational purposes with periodic boundary conditions at either end of this computational span.

The effects of film cooling have been incorporated in the form of appropriate boundary conditions at the hole locations on the blade surface. Each hole exit in its true óval shape is represented by 128 control volumes. Different velocity and temperature profiles for the injected coolant can be specified at the hole exits. For the present results, coolant flow distributions obtained from an earlier analysis
(Garg and Rigby, 1999) were specified, as detailed later.

\section{BLADE AND EXPERIMENTAL DETAILS}

The experimental data on the VKI rotor with three staggered rows of shower-head cooling holes have been provided by Camci and Arts (1985), using the short-duration VKI Isentropic Compression Tube facility. Figure 1 shows the VKI rotor geometry along with cooling hole details. Three staggered rows of cylindrical cooling holes $(\mathrm{d}=$ $0.8 \mathrm{~mm} ; \mathrm{s} / \mathrm{c}=-0.031,0,0.031$ ) were located around the leading edge. The row and hole spacings were both $2.48 \mathrm{~mm}$. These holes were spanwise angled at $30^{\circ}$ from the tangential direction and drilled in a plane perpendicular to the blade surface. The blade instrumented for heat flux measurements was milled from 'Macor' glass ceramic and 45 platinum thin films were applied on its surface. One cylindrical cavity of $4.5 \mathrm{~mm}$ diameter was drilled along the blade height to act as the plenum chamber, as shown in Fig. I. The local wall convective heat flux was deduced from the corresponding time-dependent surface temperature evolution, provided by the platinum thin-film gages. The wall temperature/wall heat flux conversion was obtained from an electrical analogy, simulating a one-dimensional semi-infinite body configuration. More details are available in Camci and Arts (1985).

\section{COMPUTATIONAL DETAILS}

A multi-block grid has been generated for the VKI rotor with three staggered rows of shower-head holes, using the commercial code GridPro/az3000 (Program Development Corporation, 1997). The grid details are shown in Fig. 2 where the leading-edge grid details are shown in two insets for the leading-edge hole $\mathrm{M}$, and the pressure- and suction-side holes $P$ and $S$. Since the hole-rows are staggered, the insets in Fig. 2 are at different spanwise sections of the blade leading edge. Also shown in Fig. 2 are the details of the surface grid over the blade (computational) span near and within the hole-exits. Initially, the grid consists of 162 blocks but before the solver is used, it can be merged into just 13 blocks using the Method of Weakest Descent (Rigby et al., 1997). The final viscous grid consists of a total of 106496 cells, with 128 cells within the full hole-exit (for hole $M$ ), and 64 cells within each of the four half-hole-exits (for holes P and S). For computational accuracy the ratio of two adjacent grid sizes in any direction was kept within 0.8-1.25. Also, following Boyle and Giel (1992), the first grid size adjacent to a solid wall, measured in wall units $\left(\mathrm{y}^{+}\right)$, is less than unity for the viscous grid. We may point out that using the commercial code GridPro/az3000, two multi-block grids were first generated for the uncooled VKI rotor for a grid independence study. One grid had twice as many cells in the streamwise direction as in the second grid. The two grids yielded nearly identical heat transfer coefficient and pressure distributions at the blade surface. We may also note that the multi-block grid has better quality and provides a much finer resolution near and over the hole exits than the single-block C-grid. Computations were run on the 16-processor C90 supercomputer at NASA Ames Research Center. The code requires about $23 \mathrm{Mw}$ of storage with all blocks in memory, and takes about $5 \mathrm{~s}$ per iteration for two levels of multi-grid. A case requires about 1200 iterations to converge.

\section{COOLANT FLOW CHARACTERISTICS AT HOLE-EXITS}

A typical hole-exit plane is shown in Fig. 3 where the local holecoordinates $s$ and $z$ are also displayed. Since the shower-head holes are cylindrical and inclined $30^{\circ}$ to the spanwise direction, the hole-exit is elliptical with an aspect ratio of 2.0. Based on the previous study 
(Garg and Rigby, 1999), the coolant flow distributions for the velocity magnitude, temperature, and turbulence quantities $k$ and $\omega$ are shown in Figs. 4 through 6 at various z-locations within the hole-exits of the leading-edge $(M)$, and pressure and suction-side holes $P$ and $S$. It may be noted that in Figs. 4 through $6, p k$ and $p \omega$ have been normalized by $\rho_{0} R T_{o}$ and $\rho_{0}\left(R T_{0}\right)^{t / 2} / c_{x}$, respectively. As is obvious from Figs. 5 and 6 , the coolant velocity and temperature distributions at the hole exits do not follow the $1 / 7$ th power-law profile, and are highly skewed by the mainstream flow for the holes P and S. Distributions of $k$ and $\omega$ at the exit of holes $P$ and $S$ are also skewed. There is some skewness (towards the suction side) in the coolant flow distributions through the leading-edge hole $M$ as well. Since these distributions are quite complicated, attempts to represent them via polynomials had to be aborted. Instead, these distributions were discretized in terms of the local coordinates $s$ and $z$, and a two-dimensional interpolation was used to define the coolant flow characteristics $(\rho V, T, \rho k, \rho \omega$ and flow angles) at any point within the particular hole-exit.

\section{RESULTS AND DISCUSSION}

Four experimental cases for the VKI rotor were analyzed for comparison. The values of various parameters for these cases are given in Table 1. These cases cover a wide range of coolant mass flow rate from $0.5 \%$ to $1.01 \%$ of the main flow rate, and the ratio of coolant temperature to mainstream stagnation temperature from 0.49 to 0.59 . The blowing parameter values, in terms of $\rho_{c} V_{c} /\left\langle\rho_{o}\left(R T_{o}\right)^{1 / 3}\right\}$, ranged from 0.111 to 0.161 for the hole $M, 0.241$ to 0.316 for the hole $P$, and 0.294 to 0.366 for the hole $S$ for the four cases. Figure 7 compares the span-averaged heat transfer coefficient on the cooled blade surface with the experimental data of Camci and Arts (1985), denoted by squares, for the four cases. The abscissa in this figure represents the surface distance along the blade normalized by the true chord, as per the experimental data of Camci and Arts (1985). The three short vertical lines at the bottom of the results for each case denote the location of shower-head cooling rows. Also shown for each case is the blade heat transfer coefficient predicted by the analysis of Garg and Rigby (1999) wherein the plenum and hole-pipes were also gridded. For the case 155, the span-averaged heat transfer coefficient on the blade, obtained by specifying the $1 / 7$ th power-law distribution for the coolant velocity and temperature, and uniform distribution of $k$ and $\omega$ at the hole exits in place of the current profiles, is also shown. A comparison of the predicted heat transfer coefficient in the leading edge region between the rows of shower-head holes is not possible due to the lack of experimental data in this narrow region. The experimental uncertainty in the measurement of heat transfer coefficient is about $5 \%$ except in the shower-head region where it is estimated to be as high as 10-15\% (Camci and Arts, 1985). This may partially account for the somewhat poor comparison in the Ieadingedge region on the pressure side.

The small differences (on the suction side of the blade) between the results using the current coolant flow distributions at the hole-exits and the earlier analysis (Garg and Rigby, 1999) wherein the plenum and hole-pipes were also gridded are due to the fact that even with 128 grid cells within the small hole opening on the blade surface, the thin boundary layer within the hole-pipe is not resolved completely unless the computation is extended inside the hole-pipe. Figure 8 shows the grid within the hole-exit for (a) the current simulation, and (b) the earlier study (Garg and Rigby, 1999). Even if the number of grid cells within the hole-exit is doubled for the current simulation, it will not be anywhere close to the resolution of the hole-rim in the earlier study. As discussed later on, it is doubtful whether such a high resolution, as used in the earlier study, is required. It is also interesting to note that using the $1 / 7$ th power-law instead of the current distributions at the hole-exits yields fairly good results as far as the span-averaged heat transfer coefficient on the blade surface is concerned. The local heat transfer coefficient values are, however, quite different as is evident from Fig. 9, where the leading-edge region is detailed for case 155 for (a) $1 / 7$ th power-law profiles at the hole-exits, (b) current profiles, and (c) when the plenum and hole-pipes are also gridded (Garg and Rigby, 1999). Figure 9 shows the heat transfer coefficient contours at an interval of $100 \mathrm{~W} / \mathrm{m}^{2}-\mathrm{K}$. Unfortunately, there are no span-resolved experimental data for comparison with the results in Fig. 9. However, it is expected that the results in Fig. 9 (c) are closer to reality than those in Fig. 9(a) or 9(b) since they are not based on any assumption about the coolant flow characteristics at the hole-exits. Clearly, the results in Fig. 9(a) are very different from those in Fig. 9(c), while those in Fig. 9(b) are quite close to those in Fig. 9(c). For local values of the blade heat transfer coefficient, therefore, proper specification of the coolant flow characteristics at the hole-exits is essential, and it is not really necessary to resolve the boundary layer along the hole-pipe as well as was done by Garg and Rigby (1999) (cf. Fig. 8(b)).

Based on the present simulation, Fig. 10 displays the heat transfer coefficient contours in the leading-edge region at an interval of 100 $\mathrm{W} / \mathrm{m}^{2}-\mathrm{K}$ for all the cases. Results for the four cases are quite similar. Holes $\mathrm{M}, \mathrm{P}$ and $\mathrm{S}$ are clearly identified for each case. Also, the span shown is exactly double of the computational span for each case, and clearly shows that the periodicity across the computational span is well maintained. Downstream of both holes $\mathrm{P}$ and $\mathrm{S}$, we observe a region of high heat transfer coefficient sandwiched between the low $h$ values near both ends of the computational span. This pattern has been observed in several computational as well as experimental studies. While Fig. 10 shows the strong spanwise non-uniformity of the heat transfer coefficient in the stagnation region over $|s / c| \leq 0.1$, these non-uniformities actually extend over $|s / c| \leq 0.3$, and may well account for the discrepancy between the experimental data and the computations (cf. Fig. 7) in this region.

\section{CONCLUSIONS}

The significance of specifying the coolant flow distributions correctly at the hole-exits on a blade has been brought out in relation to local heat transfer coefficients on a film-cooled rotor. While the span-averaged values of $h$ match well with the experimental data whether the current distributions or the $1 / 7$ th power-law is used for the coolant flow characteristics at the hole-exits, the local values of $h$ near the hole-exits are greatly affected by the coolant flow distributions. Detailed distributions of coolant velocity, temperature, $k$ and $\omega$ at the shower-head hole exits are also presented in a form that can be used for simulation of film-cooled blade characteristics. It is found that the coolant velocity and temperature distributions at the hole exits do not follow the $1 / 7$ th power-law profile, and are highly skewed by the mainstream flow for the holes $\mathrm{P}$ and $\mathrm{S}$. Distributions of $k$ and $\omega$ at the exit of holes $P$ and $S$ are also skewed. There is some skewness (towards the suction side) in the coolant flow distributions through the leading-edge hole $\mathrm{M}$ as well. 


\section{REFERENCES}

Boyle, R.J. and Giel, P., 1992, Three-Dimensional Navier Stokes Heat Transfer Predictions for Turbine Blade Rows, AIAA Paper 923068.

Camci, C. and Arts, T., 1985, Experimental Heat Transfer Investigation Around the Film-Cooled Leading Edge of a HighPressure Gas Turbine Rotor Blade, J. Eng. Gas Turbines \& Power, Vol. 107, pp. 1016-1021.

Chien, K.Y., 1982, Prediction of Channel and Boundary-Layer Flows with a Low-Reynolds-Number Turbulence Model, AIAA J., Vol. 20, pp. 33-38.

Chima, R.V., 1996, A $k$ - $\omega$ Turbulence Model for Quasi-ThreeDimensional Turbomachinery Flows, AIAA Paper 96-0248.

Garg, V.K., 2000, Heat Transfer on a Film-Cooled Rotating Blade, Int. J. Heat Fluid Flow, Vol. 21, pp. 134-145.

Garg, V.K., 1999, Heat Transfer on a Film-Cooled Rotating Blade Using Different Turbulence Models, Int. J. Heat Mass Transfer, Vol. 42, pp. 789-802.

Garg, V.K. and Ameri, A.A., 1997, Comparison of Two-Equation Turbulence Models for Prediction of Heat Transfer on Film-Cooled Turbine Blades, Numer. Heat Transfer, Part A, Vol. 32, pp. 347-371.

Garg, V.K. and Gaugler, R.E., 1993, Heat Transfer in FilmCooled Turbine Blades, ASME Paper 93-GT-81.

Garg, V.K. and Gaugler, R.E., 1994, Prediction of Film Cooling on Gas Turbine Airfoils, ASME Paper 94-GT-16.

Garg, V.K. and Gaugler, R.E., 1996, Leading Edge Film Cooling Effects on Turbine Blade Heat Transfer, Numer. Heat Transfer, Part A, Vol. 30, pp. 165-187.
Garg, V.K. and Gaugler, R.E., 1997, Effect of Velocity and Temperature Distribution at the Hole Exit on Film Cooling of Turbine Blades, J. Turbomachinery, vol. 119, pp. 343-35I.

Garg, V.K. and Rigby, D.L., 1999, Heat Transfer on a FilmCooled Blade - Effect of Hole Physics, Int. J. Heat Fluid Flow, Vol. 20, pp. 10-25.

Goldstein, R.J., 1971, Film Cooling, Advances in Heat Transfer, Vol. 7, pp. 321-379, Academic.

Hylton, L.D., Nirmalan, V., Sultanian, B.K. and Kaufman, R.M., 1988, The Effects of Leading Edge and Downstream Film Cooling on Turbine Vane Heat Transfer, NASA CR 182133.

Jameson, A., Schmidt, W. and Turkel, E., 1981, Numerical Solutions of the Euler Equations by Finite Volume Methods Using Runge-Kutta Time-Stepping Schemes, AIAA Paper 81-1259.

Menter, F.R., 1993, Zonal Two-Equation $k-\omega$ Turbulence Models for Aerodynamic Flows, AIAA Paper 93-2906.

Program Development Corporation, 1997, "GridPro ${ }^{\mathrm{TM}} / \mathrm{az3000}$ User's Guide and Reference Manual," White Plains, NY.

Rigby, D.L., Steinthorsson, E. and Coirier, W.J., 1997, Automatic Block Merging Using the Method of Weakest Descent, AIAA Paper 97-0197.

Steinthorsson, E., Ameri, A.A. and Rigby, D.L., 1997, TRAF3D.MB - A Multi-Block Flow Solver for Turbomachinery Flows, AIAA Paper 97-0996.

Wilcox, D.C., 1994, Simulation of Transition with a TwoEquation Turbulence Model, AIAA J., Vol. 32, pp. 247-255.

Table 1 Parameter values for the cases analyzed

$$
M_{\text {in }}=0.251, M_{e x, s}=0.905, \operatorname{Re}_{c, \text { in }}=8.42 \times 10^{5}, \mathrm{Tu}_{\mathrm{in}}=5.2 \%
$$

\begin{tabular}{||c|c|c|c|c|c||}
\hline case & $\mathrm{p}_{0}, \mathrm{kPa}$ & $\mathrm{T}_{0}, \mathrm{~K}$ & $\mathrm{~T}_{w} / \mathrm{T}_{0}$ & $\mathrm{~T}_{c} / \mathrm{T}_{0}$ & $\mathrm{~m}_{\mathrm{c}} / \mathrm{m}_{\mathrm{o}}$ \\
\hline 155 & 289.5 & 409.5 & 0.727 & 0.52 & $0.62 \%$ \\
\hline 154 & 288.3 & 408.9 & 0.722 & 0.52 & $0.50 \%$ \\
\hline 157 & 289.1 & 409.3 & 0.731 & 0.49 & $1.01 \%$ \\
\hline 120 & 292.6 & 410.3 & 0.727 & 0.59 & $0.57 \%$ \\
\hline
\end{tabular}



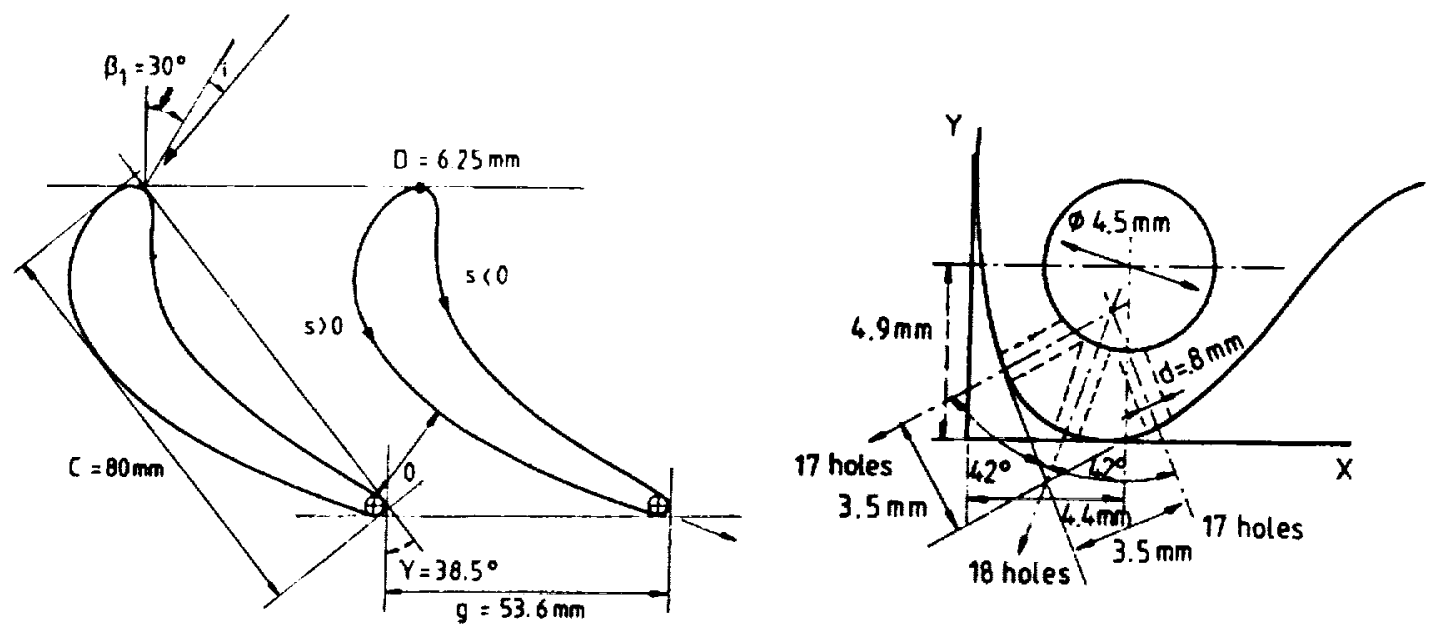

Fig. 1 VKI rotor and shower-head cooling hole details
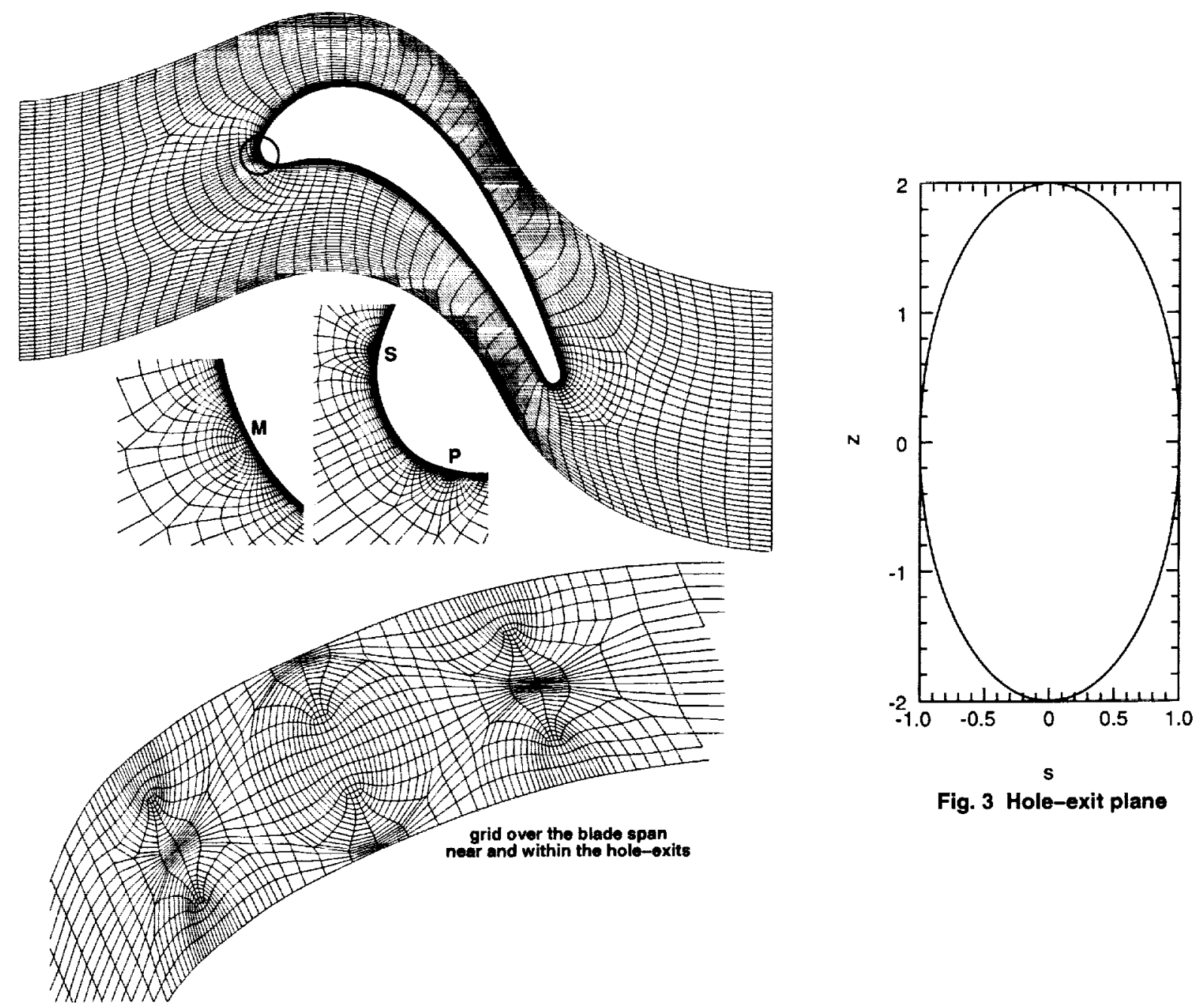

Fig. 2 Viscous grid over the VKI rotor 

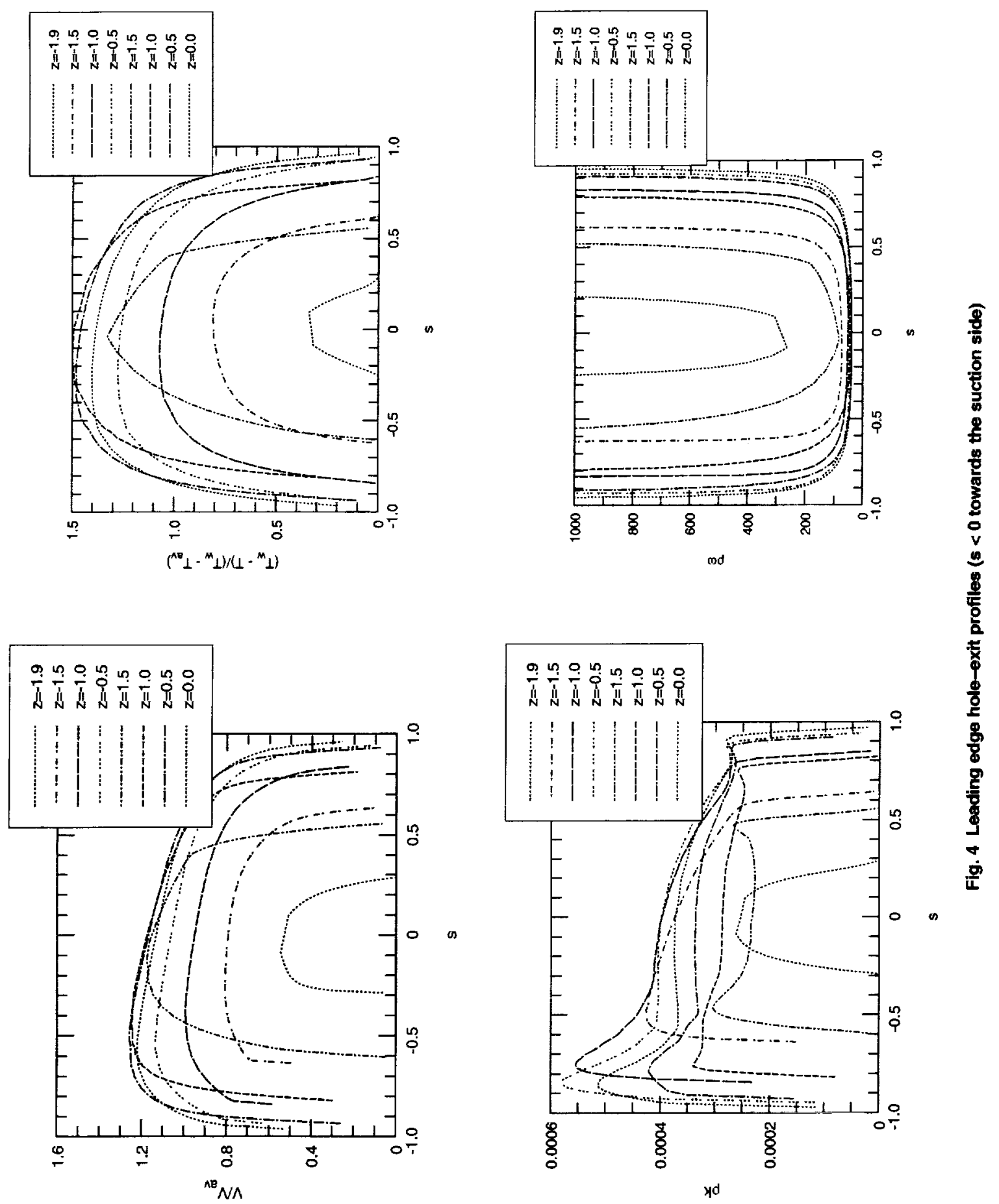

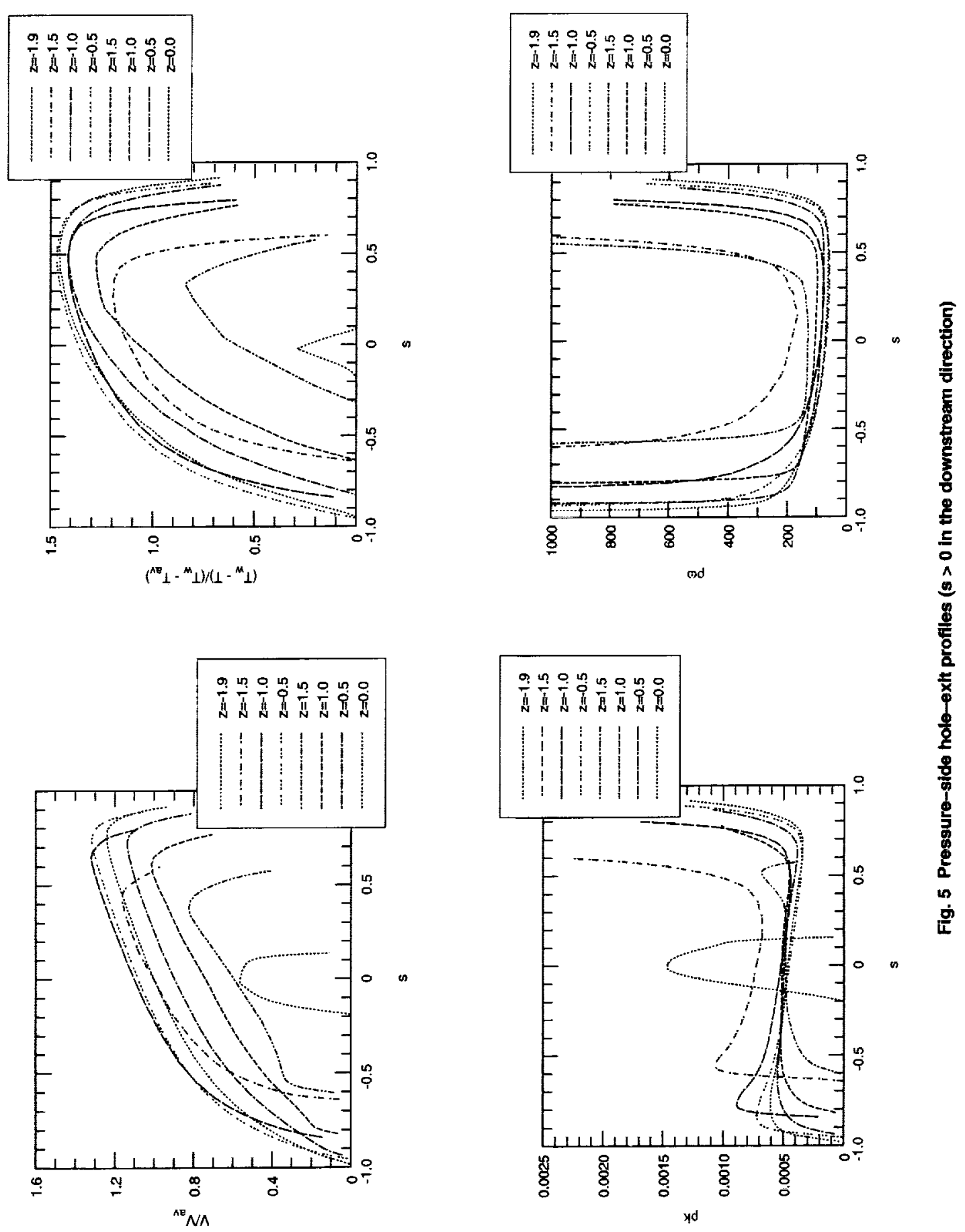

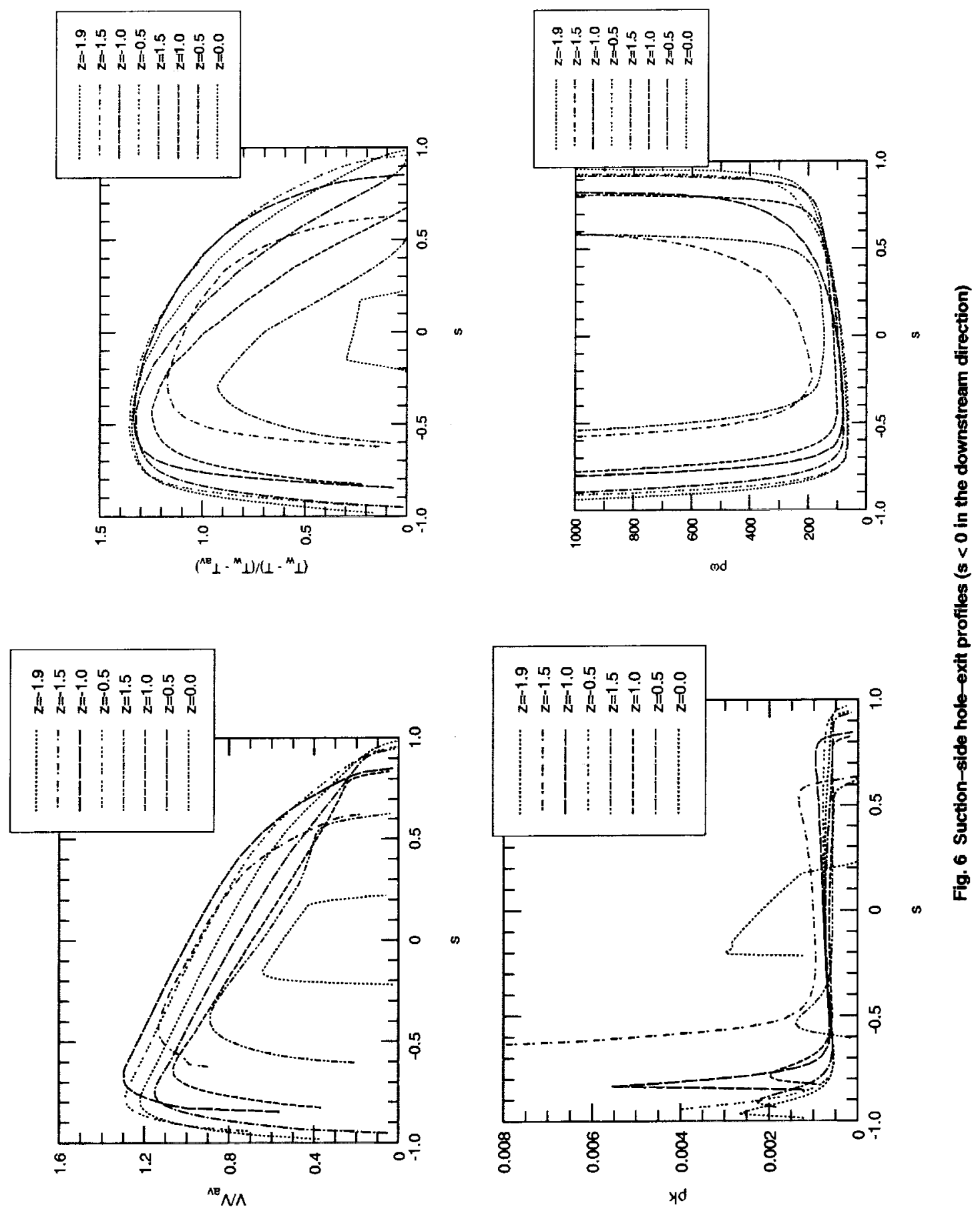

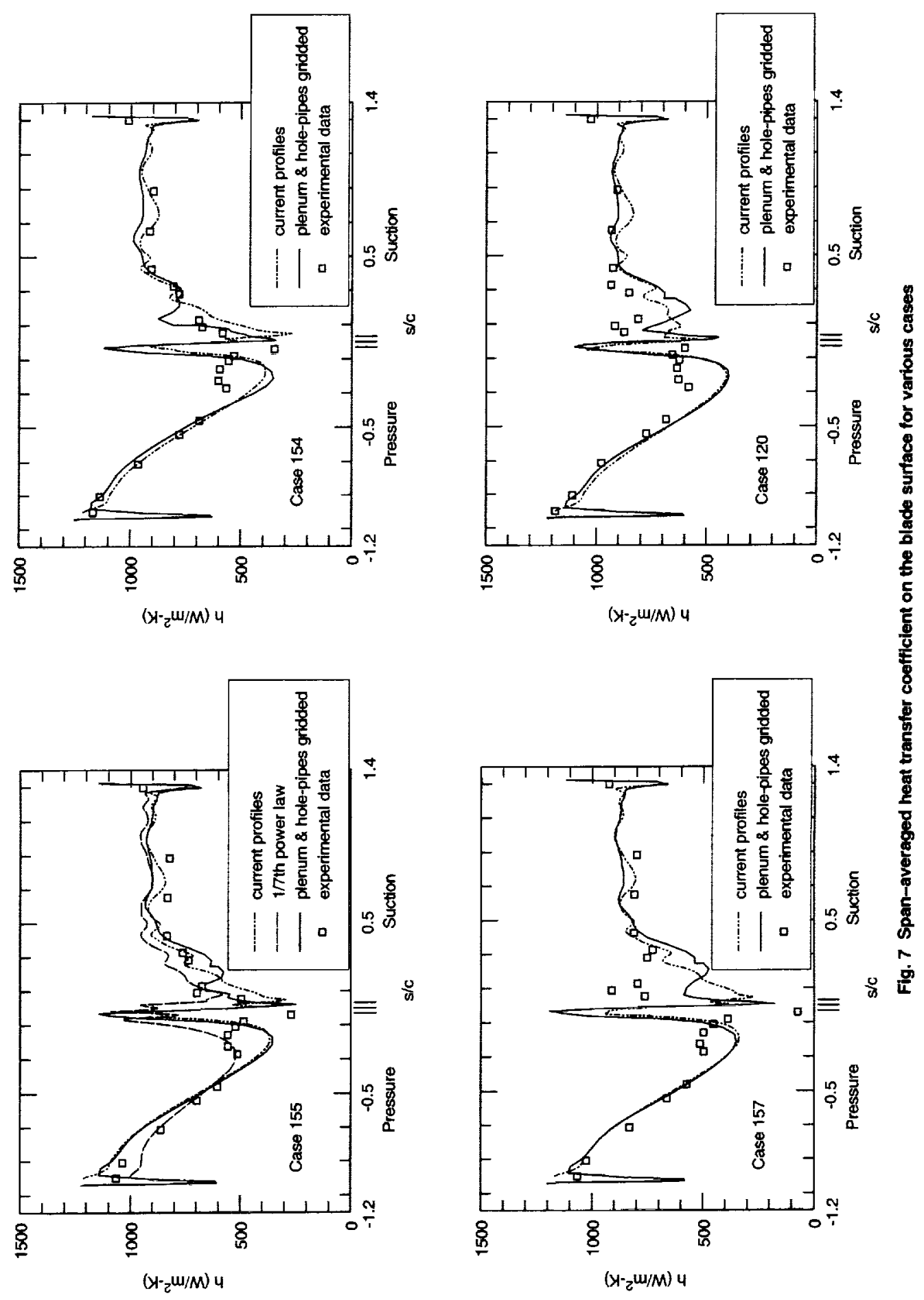

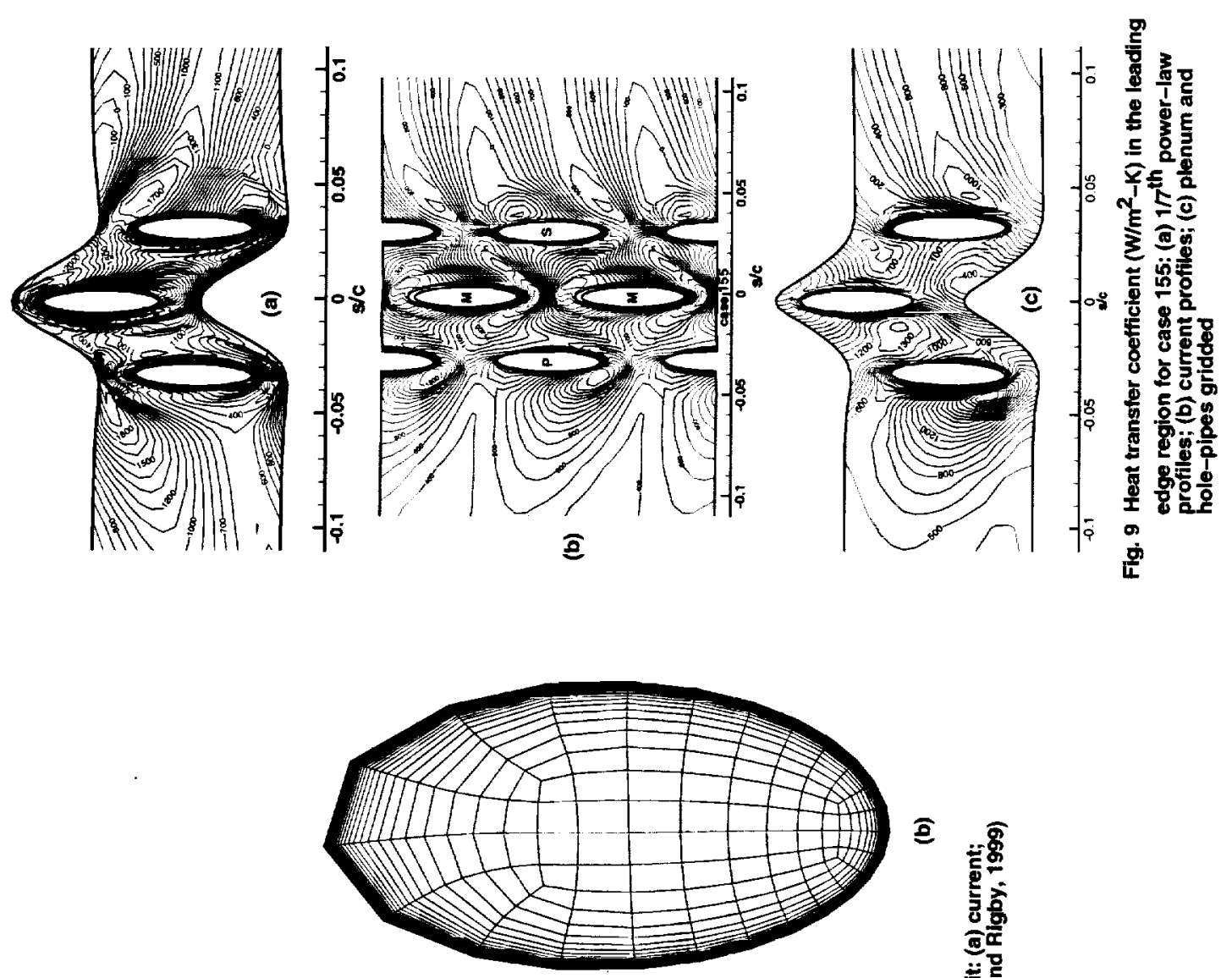

a
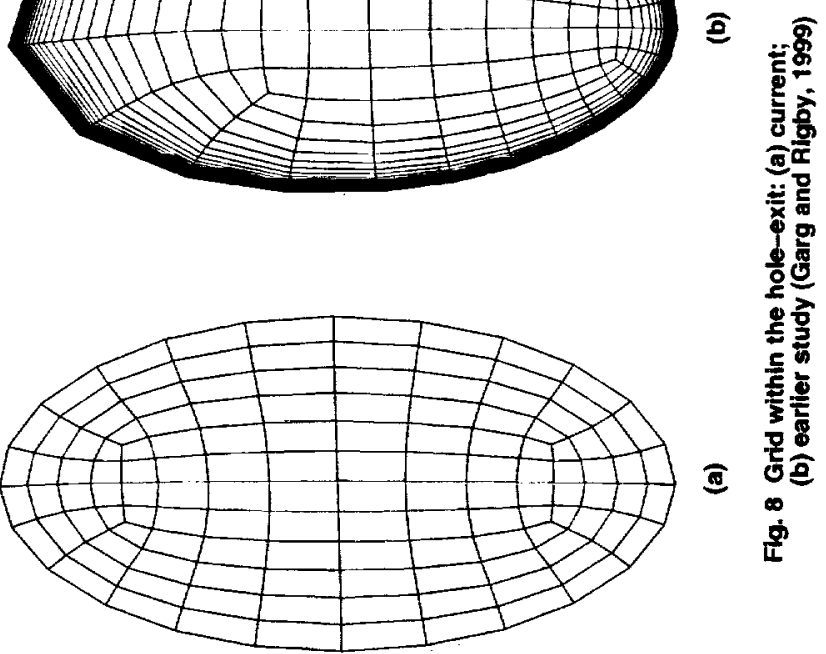

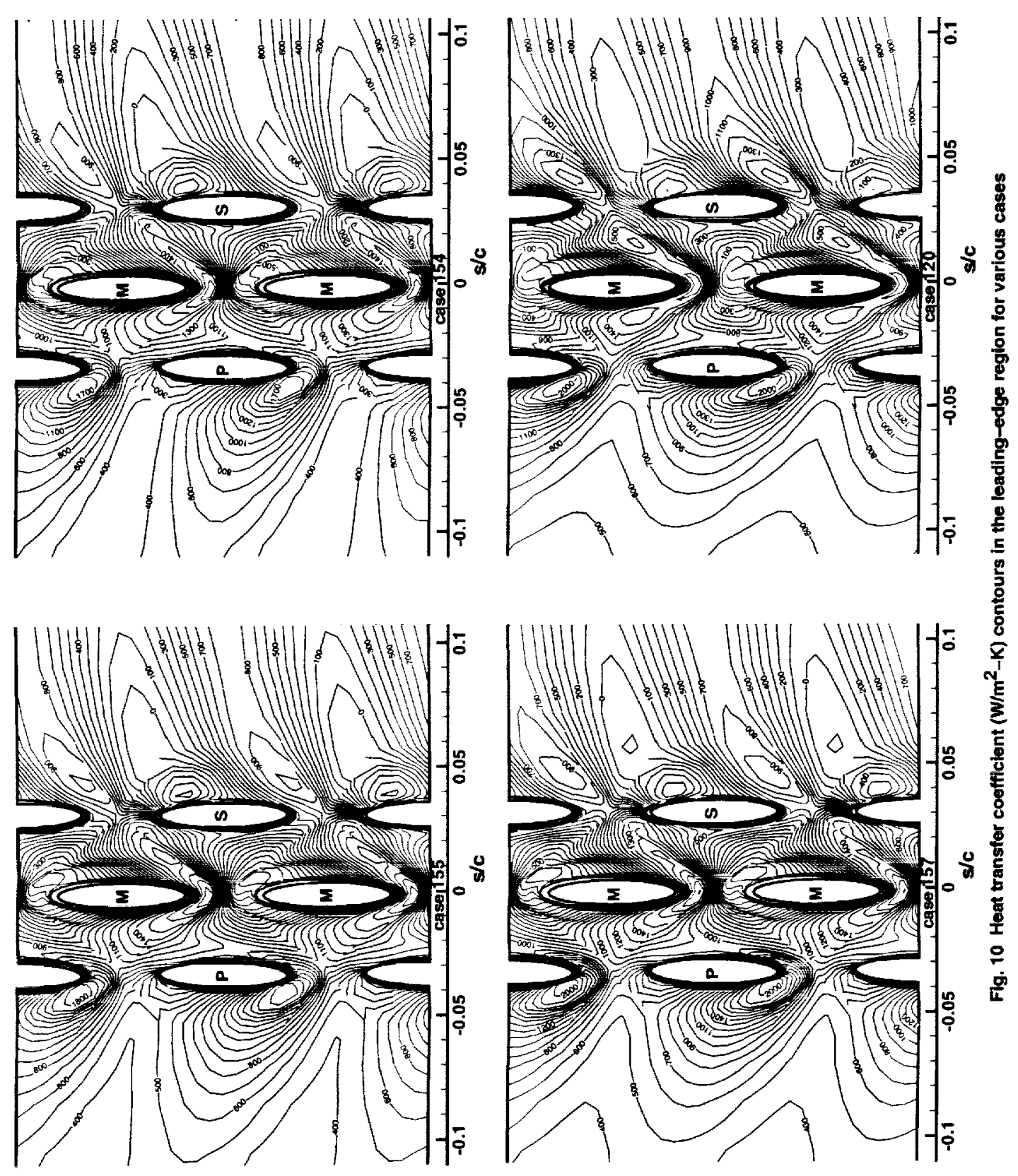


\begin{tabular}{|c|c|c|c|c|}
\hline \multicolumn{3}{|c|}{ REPORT DOCUMENTATION PAGE } & & $\begin{array}{l}\text { Form Approved } \\
\text { OMB No. 0704-0188 }\end{array}$ \\
\hline \multicolumn{5}{|c|}{ 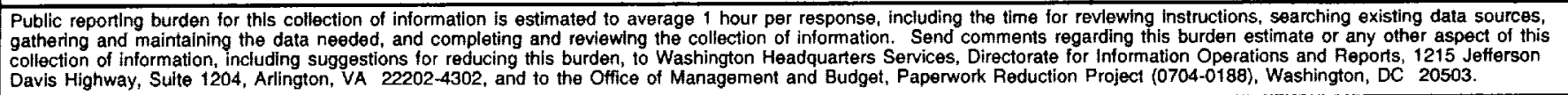 } \\
\hline 1. AGENCY USE ONLY (Leave blank) & $\begin{array}{r}\text { 2. REPORT DATE } \\
\text { October } 2000\end{array}$ & \multicolumn{3}{|c|}{$\begin{array}{l}\text { 3. REPORT TYPE AND DATES COVERED } \\
\text { Final Contractor Report }\end{array}$} \\
\hline \multicolumn{3}{|c|}{$\begin{array}{l}\text { 4. TITLE AND SUBTITLE } \\
\text { Modeling Film-Coolant Flow Characteristics at the Exit of Shower-Head Holes }\end{array}$} & \multirow{2}{*}{\multicolumn{2}{|c|}{$\begin{array}{l}\text { 5. FUNDING NUMBERS } \\
\text { WU-523-26-13-00 } \\
\text { NAS3-98106 }\end{array}$}} \\
\hline \multicolumn{3}{|l|}{$\begin{array}{l}\text { 6. AUTHOR(S) } \\
\text { Vijay K. Garg }\end{array}$} & & \\
\hline \multicolumn{3}{|c|}{ 7. PERFORMING ORGANIZATION NAME(S) AND ADDRESS(ES) } & \multicolumn{2}{|c|}{$\begin{array}{l}\text { 8. PERFORMING ORGANIZATION } \\
\text { REPORT NUMBER }\end{array}$} \\
\hline \multicolumn{3}{|c|}{ 9. SPONSORING/MONITORING AGENCY NAME(S) AND ADDRESS(ES) } & \multicolumn{2}{|c|}{$\begin{array}{l}\text { 10. SPONSORINGMONITORING } \\
\text { AGENCY REPORT NUMBER } \\
\text { NASA CR-2000-210510 }\end{array}$} \\
\hline \multicolumn{5}{|c|}{$\begin{array}{l}\text { 11. SUPPLEMENTARY NOTES } \\
\text { Prepared for the } 2000 \text { International Mechanical Engineering Congress and Exposition sponsored by the American Society } \\
\text { of Mechanical Engineers, Orlando, Florida, November 5-10, 2000. Project Manager, R.E. Gaugler, Turbomachinery and } \\
\text { Propulsion Systems Division, NASA Glenn Research Center, organization code 5820, 1-216-433-5882. }\end{array}$} \\
\hline \multirow{2}{*}{\multicolumn{3}{|c|}{ 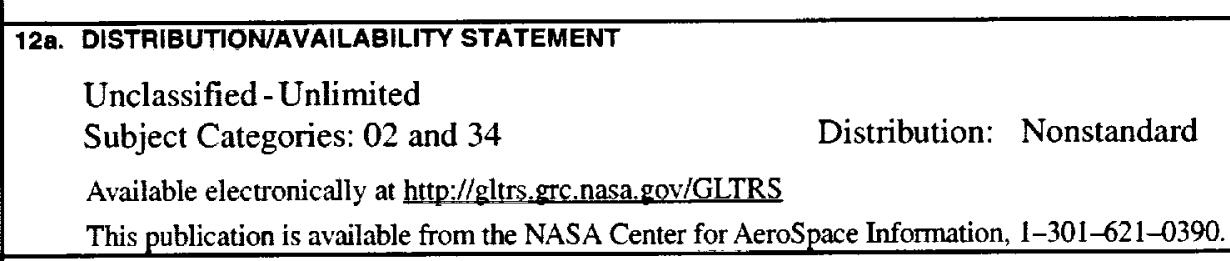 }} & \multirow{2}{*}{\multicolumn{2}{|c|}{ 12b. DISTRIBUTION CODE }} \\
\hline & & & & \\
\hline \multicolumn{5}{|c|}{$\begin{array}{l}\text { The coolant flow characteristics at the hole exits of a film-cooled blade are derived from an earlier analysis where the } \\
\text { hole pipes and coolant plenum were also discretized. The blade chosen is the VKI rotor with three staggered rows of } \\
\text { shower-head holes. The present analysis applies these flow characteristics at the shower-head hole exits. A multi-block } \\
\text { three-dimensional Navier-Stokes code with Wilcox's } k \text { - } \omega \text { model is used to compute the heat transfer coefficient on the } \\
\text { film-cooled turbine blade. A reasonably good comparison with the experimental data as well as with the more complete } \\
\text { earlier analysis where the hole pipes and coolant plenum were also gridded is obtained. If the } 1 / 7 \text { th power law is } \\
\text { assumed for the coolant flow characteristics at the hole exits, considerable differences in the heat transfer coefficient on } \\
\text { the blade surface, specially in the leading-edge region, are observed even though the span-averaged values of } h \text { match } \\
\text { well with the experimental data. This calls for span-resolved experimental data near film-cooling holes on a blade for } \\
\text { better validation of the code. }\end{array}$} \\
\hline \multicolumn{4}{|l|}{ 14. SUBJECT TERMS } & $\begin{array}{c}\text { 15. NUMBER OF PAGES } \\
18\end{array}$ \\
\hline \multirow{2}{*}{\multicolumn{3}{|c|}{ Film-cooling; Modeling; Shower-head holes; Heat transfer }} & & 16. PRICE CODE \\
\hline & & & & \\
\hline $\begin{array}{l}\text { 17. SECURITY CLASSIFICATION } \\
\text { OF REPORT } \\
\text { Unclassified }\end{array}$ & $\begin{array}{l}\text { 18. SECURITY CLASSIFICATION } \\
\text { OF THIS PAGE } \\
\text { Unclassified }\end{array}$ & $\begin{array}{l}\text { 19. SECUAITY CLASSIFIC } \\
\text { OF ABSTRACT } \\
\text { Unclassified }\end{array}$ & ATION & 20. LIMITATION OF ABSTRACT \\
\hline
\end{tabular}

